\title{
Artistic Trends in Children Cinema of Post-Soviet Kazakhstan
}

\section{Gulnara Mursalimova}

\author{
Alma Aidarova \\ Bekbolat Yedilbayev
}

Kazakh National Academy of Arts named after T. Zhurgenov

gulnara-mursalimova@mail.ru

\section{Doi:10.5901/mjss.2015.v6n2s4p95}

\begin{abstract}
This article is dedicated to modern children cinema of Kazakhstan: themes, subjects and characters. The authors consider children films as well as such branches of film industry like "art cinema" and "auteur cinematography" with children and teenagers the main characters. Applying comparative and contrastive analysis, the authors of this article distinguish major artistic mainstreams in the field of children cinema and films dedicated to children and juveniles in the period from 1991 to 2013.
\end{abstract}

Keywords: Kazakh cinema, Children cinema, Children's images [characters] in Kazakh cinema.

\section{Introduction}

Children cinema as well as images of children and teenagers in feature films have always been of particular interest to directors. Kazakh cinema is no exception.

Kazakh children feature film industry has been insufficiently studied, despite the fact it is characterized by own distinctive development trends. The conventional children feature film model as such saw its peak of development in the 1960s and 1970s and was particularly expressive in the works by film directors A.Karsakbaev ("My Name is Kozha," 1963), Sh.Beisembaev ("Arman Ataman," 1967), K.Kasymbekov ("Shok and Sher," 1972). In 1990s and the following years the established children cinema model undergoes a significant transfromation in the field of "auteur cinematography", which is particularly can be traced in such well-known films by K.Salykov ("Balcony," 1988), S.Narymbetov ("Life Story of Young Accordionist," 1993), D.Omirbaev ("Cardiogram," 1995), S.Aprymov ("Three Brothers," 2000), A.Kulbaev ("Swift," 2008) and others.

There are two periods of children feature film industry development: the Soviet and modern post-Soviet stages differ with various levels of aesthetic interpretation and demonstration of child psychology on screens, and educational functions of cinematographer. The films are being explored in terms of children cinema subject-matter development, the evolution and transformation of the Soviet children cinema genre and the formation of auteur cinematography of the "Kazakh New Wave" in the 1990s and within the independent 2000s.

The main objective of the study is to trace and explore the Kazakh children feature film industry, starting from 1950s and until 2010s, as a single continuous cinematic process. The authors study films classifying them into two categories: 1) films for children and youth, 2) films about children and teenagers. The article studies and summarizes film materials by decades with regard to children and youth issues; pinpoints the dramaturgical structure of films, the visualization of the images of children and adolescents, the reflection of national mind-set, and spiritual values in the most iconic films. The development stages of Kazakh children feature cinema are considered not only in the context of the cinematic process of Kazakh national cinema industry but also in the overall social and cultural context of the Soviet society development and transition from totalitarianism to democracy.

\subsection{Research methods}

The study of children feature cinema of Kazakhstan is based on comparative, artistic, historical and film research methods, as well as comparative and chronological, and scientific classification, and analytical principles of organization of studied materials. 
Kazakh feature cinema was the subject of study by such American film experts like Jane Knox-Voina (J. KnoxVoina, 2010), Stefan Norris (S. M. Norris, 2010) and English historian of cinema, professor Birgit Beumers (B. Beumers, 2010, p.203-209). However, their studies either did not cover or paid minor attention to children cinema as well as the images of children and adolescents in the films targeted at mature (adult) audience.

\section{The Origin and Development of Kazakh Children Cinema during the Soviet Times}

Before analyzing film projects, it is necessary to define the notion of "children cinema."

Children cinema includes cinema art works, and feature films targeting children and youth audience in this particular case. The main characters in children films are, as a rule, represented by children and teenagers. Therefore, "children cinema" implies cinematographic works "about children" and "for children." In terms of genre affiliation, "children cinema" is categorized into comedy, comic strip, fantasy and adventure films. In world cinema industry, the presentation of children and adolescents' characters raising serious issues for people's comprehension, but which are, though, not targeted at young audience, is practiced. In this article, we are going to study both children cinema and films with major characters represented by children and teenagers but which are made not for young audience.

The first children films in the world were shot in Tsarist Russia in 1910s. The cinematic trend continued actively developing in the USSR. Children films of the Soviet Union were closely associated with the communist ideology, and were meant (designed) to educate younger generations.

Children cinema of Kazakhstan emerged in 1950s. A film project about young naturalists "Winged Gift" (1956, director A.Slobodnik), based on the novel "Azamat Eagle" by M.Zverev, is believed to be the first children film. Athough the Kazakh children cinema was an important outpost of the Soviet ideology at first, it was to some extent free from the totalitarian framework typical for the preceding Stalin-era. Director Abdullah Karsakbaev, who shot "My Name is Kozha" in 1963 - based on the eponymously play by children's story writer Berdibek Sokpakbaev, and that has distinctive national identity and symbolic features, and expressively demonstrates the inner world of the main characters-, founded the Kazakh children cinema and "School of A.Karsakbaev," the traditions and guidelines of which could be also traced in the works by other Kazakh filmmakers and directors.

In 1970s - the beginning of 1980s films demonstrating the tender feelings of youth and awkward age challenges, adventure films, military drama movies as well as the first fairy-tale films and films of various genres for children and about children were produced. This period is characterized by focus on the psychological portrait of young characters, as well as communication and relations problems of characters of different age. The peculiarities of this period are believed to be another stage of children cinema evolution in the context of various feature film genres.

\section{Children Cinema and Images of Children and Teenagers in Cinematography of the Post-Soviet Kazakhstan}

New artistic trends in modern children cinema of Kazakhstan emerged during the Perestroika and Glasnost period that shattered the ideological principles of the Soviet totalitarian regime. Democratic processes in the society entailed dramatic, fundamental changes both in the field of culture and art.

In the late 1980s, after making a debut in the field of feature cinema by releasing full-length pictures, a group of young directors in the Kazakh cinematography introduced a cinematic trend that would go down into history as the "Kazakh New Wave." The projects by the "Kazakh New Wave" representatives - "The Needle" (1988, director R.Nugmanov), "The Last Stop" (1989, director S.Aprymov), "Kairat" (1991, director D.Omirbaev), "Rival in Love" (1991, director A.Karakulov) stood out from other works by absolutely new feature film style and distinctive artistic principles. Further film projects by directors mentioned above would be dedicated to children and teenagers. The films "Cardiogram" (1995) by D.Omirbaev, "The Last Holidays" (1996) by A.Karakulov, and "Three Brothers" (2000) by S.Aprymov demonstrated drastic transformation of children and adolescents' images. Let us analyze these films in detail.

Directors of these auteur films, by means of cinematic instruments, make a slashing criticism of the Soviet society they as well as their screen characters, children and adolescents, lived in. These films are not "enjoying" wide popularity since the authors' insight and philosophical beliefs, their inner feelings and emotions are conveyed through characters' behavior. They show children and teenagers becoming segregated from society, school and their families. They are lonely, and, sometimes, growing completely hopeless, they start using drugs and committing crimes. On the one hand, we can conclude they tell the stories of troubled teens. Social problems also occurred in the Soviet Union, but through censorship they were not properly reflected in films. The tendency of displaying social problems in feature films with the help of characters revealed itself in the first decade of independence. The narrative and presentation of the time in the films mentioned above harshly criticized the visionless Soviet ideology, and the characters demonstrated on screens the 
real state of things and achievements of the Perestroika period. And this is the main distinctive feature of the Kazakh auteur cinema. Further films by the same directors would be also dedicated to teenagers, but their artistic idea, structure, and style would be different. Film expert, professor Bauyrzhan Nogerbek studies in his monograph the films mentioned as well as the creative work of other filmmakers and directors as an example of anti-totalitarian cinema, and marks: "Many cinematographers of the post-Soviet cinema, including authors of the "Kazakh New Wave" believe they produced and keep producing "different films." There is a deal of truth in it. The practical experience of filmmaking in Kazakhstan in 1990s proves that young filmmakers and directors, first of all, deliberately refused from the Soviet totalitarian film model, and began intentionally destroying the myths propagandized on Soviet screens, and unveiling cinematic ideological phrases and lies about the Soviet reality, and, to some extent, tried to introduce to the cinema industry new antitotalitarian film patterns" (B. R. Nogerbek, 2008, p.281).

Soon, except for the "Kazakh New Wave" representatives, all Soviet cinematographers of that period joined the mainstream and demonstrated the Soviet mentality. The trend was borrowed then by Central Asia countries. Importantly, the process covered also children cinema. Kazakhstan film expert Gulnara Abikeeva thoroughly studies the issue in her monograph [5]. We will focus only on some ideas of the author with regard to children cinema. G.Abikeeva writes: "This character "embodies" national traditions. It is a boy from the "Selkinchek" (1993) by director Aktan Abdykalykov, young accordionist from the "Life Story of Young Accordionist" (1995) by S.Narymbetov, boys Georg and Orazka from the film "Little Angel, Bring Happiness" (1992) by director U.Saparov, teenager from the "Cardiogram" (1995) by director D.Omirbaev and grandson of Stepanych from the "Shanghai" (1996) by director A.Baranov. Again, children became the heroes of the early period of independence, symbolizing the revival of new nations and statehood formation" (G.O.Abikeeva, 2006, p.146).

The film "Cardiogram" (1995, written and directed by D.Omirbaev) is also dedicated to child-related issues. New artistic principles are distinctively expressed in D.Omirbaev's works. The director stands out form other directors of the "Kazakh New Wave" and other filmmakers of the Kazakh cinematography demonstrating his own style. In the film "Cardiogram", a boy named Jasulan gets into new environment as he moves far away from his native place and family. As soon as he boards a bus, he seems to start a new life, as if he was born again.

The entire atmosphere in the film is based on the real presentation of society. The vision of the film protagonist, Jasulan, reflects the perception of people surrounding him. Through his perception of the people surrounding him and certain things, through his vision and attitude, the authors describe thus the psychological features of modern society and cinematography, which is striving to demonstrate on screens inadequate behavior of children and teenagers. According to director, Jasulan has his "Cardiogram" at health camp; and puts a big question mark at the end of the picture. Jasulan, like a thief, hides in the trunk of an automobile that arrives to the camp. The car's doors get closed and the screen fades to black. This scene distinctly demonstrates that the inner world of Jasulan cannot be "reversed." He does not try to efface from his mind all he has seen and gone through; on the contrary, he gains a priceless experience. Perhaps, he may return back to his family and enjoy the family reunion, or, perhaps, he might gain respect and recognition in the future. However, his future destiny remains unknown.

The main characters of Amir Karakulov's film "The Last Holidays" (1996) are three teenagers from urban area who study at the same school. They do not care about study, some other aspects of adult life they are looking so eagerly for attract them. They are leading idle life, and use drugs together with some adults. One day, the three friends decide to take up music. Their stealing musical instruments and spirits from a bar enhances the intensity of emotions. Certain similarity can be traced between their characters and manners and the manners and qualities of some group of teenagers of school age. One of the characters named Volodya is hardly beaten by police officers and dies. His friends desire to take revenge on Volodya's stepfather for his death results, eventually, in murder. The director makes an attempt to justify his characters as they are just teenagers who have not matured yet. For instance, it is clearly shown through certain episodes, with an episode when a cross lost by an unknown girl is eventually found in Volodya's hand one of them. The teenager tries thus to atone his sins for past mistakes in his life, that appears to be short. Another character named Zhenya wants to save his friends and takes the blame upon himself, and at the end of the film he surrenders to police on his own. But he still escapes during the arrest. It does not mean that he is afraid of being held responsible for the crime, but that he is an average, weak and powerless teenager. The third character introduced as Erkin (means "Free" in Kazakh), is at liberty, but "will he be able to adopt to new school year?" is the question.

All stated above proves that they are not troubled teenagers. And apparently, their committing a crime should be blamed on education, their adult friends and society. It is a sort of message to adults about young men transiting from adolescence into adulthood. Professor Bauyrzhan Nogerbek states in his monograph the following: "In his film "The Last Holidays" A.Karakulov openly shows the negative aspects of the school time of Soviet teenagers: two-facedness and hypocrisy of parents and teachers, and fragments of documentary showing Soviet citizens enjoying a celebratory 
demonstration, and preceding the beginning of the film, contrast and pinpoint the mismatch between the declared party slogans and true state of things at a Soviet school, where there are lie, drug abuse and crimes" (B.R.Nogerbek, 2008, p.300-301).

The film "Three Brothers" (2000, written and directed by S.Aprymov) tell a story about children and teenagers on holidays, i.e. out of school time. They get together and decide to go all the way to achieve their goal. A senior man Klyain tells them a story about a train going to a fairyland. But, in fact, this train appears to be a target for Soviet missiles. This film teaches that children's dreams and fantasies sometimes lead to accidents. B.R.Nogerbek notes: "In the film "Three Brothers", behind the illusive fabulousness of the screened story narrated by the hero-character, a military pilot (his face and his adult presentation are not visible to audience, we only find out who he is in the course of events, that the narrator was, perhaps, one of the boys who, luckily, did not get into that "ill-fated" train targeted by the Soviets), the attention is drawn to the dramatic times of the Soviet totalitarian regime, when peaceful populace became victims of state military machine. "The children dreaming to get to the fairy lake and becoming the victims of the Soviet missiles" is an expressive image metaphor for the Soviet order and mode of life" (B.R.Nogerbek, 2008, p.288).

In the post-Soviet period of Perestroika, social phenomena in the society impacted on the images of teenagers in the cinema industry, methods for the cinematic presentation of characters and surroundings on the screen. The transformation of Kazakh children feature film industry is associated with this particular period.

Themes and stylistic features of the cinematic instruments of filmmakers representing the "New Wave", the content and structure of films, the selfconsiousness of "screen" characters reflect the true realities of the "transition" period, and, to certain extent, stress the distinctive features of the Kazakh auteur cinema including children films.

Therefore, films about children and teenagers produced in 1990s, through the images of average, neglected children and teenagers as well as their complex lives, reflect the very core sense of the society that became the victim of the Soviet ideology.

In 2000-2009, three directions in the field of films about teenagers and children were distinguished. In films of the period after the "New Wave", the nature of teenagers is presented not by means of showing their inner world, but, predominantly, by means of focusing on their external behaviour. In this case, characters resist not the legacy of the past, but realities of concrete society ("Shyza," 2004, by director G.Omarov, "Swift," 2008, by director A.Kulbai). Besides, this very period is distinguished by the re-introduction of the aesthetics of children films introduced by A.Karsakbaev. This trend is typical for directors D.Salamat ("Baiterek," 2009), and S.Kurmanbekov ("Seker," 2009). Also, independent commercial cinema developed - films by E.Rakishev ("Orphans", 2008), ("My Name is also Kozha," 2009). The titles of the films reflect the processes of revival of the Kazakh children cinema in modern cinema process.

In modern film industry, the enhanced role of genre children cinema can be observed - films of Hollywood style targeting box office receipts. In the Kazakh feature cinema industry of the last decade, new genres like fantasy - "The Book of Legends. Secret Forest" (director: A.lbraev, 2012), and comic strip films - "Super Bakha" (director: T.Baitukenov, T.Kasymzhanov) emerged. The authors apply graphical visual effects to attract children audience, tempted by American products. However, it can be hardly about domestic industry competing for audience yet.

To conclude, children and teenagers are interested in films highlighting contemporary issues that are close to them, eradicating joy and, sometimes, demonstrating sadness. Such films should be based on interesting life stories of children and teenagers. Therefore, there is a high demand on pictures about life of children and teenagers the main goal of which is to cultivate in others such necessary in modern society qualities like kindness, friendship, patriotism, humanism, leadership, strength and willingness. However, no proper solutions to the problem have been offered yet.

\section{References}

Abikeeva G.O. (2006). The construction of national identity in Kazakhstan and other Central Asia countries, and how this process is reflected in cinema industry. Almaty: "Center of Central Asian Cinematography", p.308.

Beumers B. (2010). "Waves, Old and New, in Kazakh Cinema," Studies in Russian and Soviet Cinema, Volume 4, Number 2, Bristol, pp. 203-209.

Knox-Voina J. (2010). "Young Kazakh Filmmakers: New "New Wave" on the Road," "KinoKultura" Online Journal, 27, http://www. kinokultura.com/2010/27-knoxvoina.shtml

Nogerbek B.R. (2008). Screen folklore traditions in Kazakh feature film industry. - Almaty: RUAN, p.376.

Norris S. M. (2010). "The Gifts of History: Young Kazakh Cinema and the Past", "Kinokultura" Online Journal, 27, http://www. kinokultura.com/2010/27-norris.shtml 